\title{
Effect of Inclusion Heat Treated Jatropha Meal in Wethers Ration on Feed Intake, Blood Parameter and Ruminal Fermentation in Short-Term Feeding
}

\author{
Renlong Lv ${ }^{1 *}$, Ken-Ichi Horiguchi ${ }^{2}$, Shin-Ichi Tagawa ${ }^{3}$, Shoichi Ichihara ${ }^{4}$ and \\ Norio Yoshida ${ }^{5}$ \\ ${ }^{1}$ Tropical Crops Genetic Resources Institute, Chinese Academy of Tropical Agricultural \\ Sciences, Danzhou, 571737, China \\ ${ }^{2}$ Faculty of Agriculture, Yamagata University, Tsuruoka, Yamagata, 997-8555, Japan \\ ${ }^{3}$ Shimizuko Shiryo Co., Ltd, Ishinomaki, Miyagi, 986-0846, Japan \\ ${ }^{4}$ Sumitomo Corporation Tohoku, Co., Ltd, Sendai, Miyagi, 980-0021, Japan \\ 5Japan Grassland Agriculture and Forage Seed Association, Chiyoda, Tokyo, 101-0035, \\ Japan
}

\begin{abstract}
A B S T RA C T
The objective of the study was to investigate feed intake, blood biochemistry, liver function, and ruminal fermentation in sheep fed heat-treated jatropha meal. The experiment was performed twice (experiment I and II). The subjects were 6 wethers. They were divided into two treatments (rapeseed diet and jatropha diet) randomly and were tested by using a cross over method. Rapeseed meal and jatropha meal were relaced to the feed as a concentrate with proportion of $5 \%$ in experiment I and $10 \%$ in experiment II. The ingestion rate of sheep fed the jatropha diet was lower than that of the rapeseed diet. The feed of jatropha diet and rapeseed diet were all ingested in experiment I. However, jatropha meal treatment left a large amount in experiment II. According to the above results, there was no obvious difference of blood characteristics between two treatments in experiment I and II, and no difference of Ruminal $\mathrm{pH}$ and total volatile fatty acids concentration between two experimental diets, and the palatability of jatropha meal showed to be bad. However, the blood parameter and rumen fermentation did not show any abnormal value after using jatropha meal of $5 \%$ and $10 \%$ of concentrate in sheep.
\end{abstract}

\begin{tabular}{l} 
Article Information \\
Received 27 May 2019 \\
Revised 27 July 2019 \\
Accepted 11 September 2019 \\
Available online 04 May 2020 \\
Authors' Contribution \\
\hline RL and ST conducted the research \\
and wrote the manuscript. KH \\
supervised the project. SI and NY \\
revised the manuscript. \\
Key words \\
Feed intake, Jatropha meal, Blood \\
parameter, Ruminal fermentation, \\
Adding ratio
\end{tabular}

\section{INTRODUCTION}

$\mathbf{J}$ atropha (Jatropha curcas L.) is a large bush belonging to the Euphorbiaceae family. It is widely distributed in American, Southeast Asian, and African countries in tropical and sub-tropical areas (Gubitz et al., 1999). Wild animals are sensitive to the poison in jatropha, so it has been used as a fence to protect crops in India and other areas (Heller, 1996). The seed kernel of jatropha contains over $63 \%$ oil (Akbar et al., 2009). Oil prices are likely to stay high in the future, which will encourage the cultivation of oilseed crops, including jatropha, for the production of bio-oil. With the increasing production of jatropha, the production of its by-products will increase too. Recycling of by-products will also become an important issue. Crude protein accounts for $27-30 \%$ of the mass of

\footnotetext{
* Corresponding author: Ivrenlong@aliyun.com 0030-9923/2020/0005-1647 \$ 9.00/0

Copyright 2020 Zoological Society of Pakistan
}

jatropha seeds. Thus, the oil residue ("jatropha meal") has potential for use in animal diets as a protein source (Makkar and Becker, 2009).

Jatropha seeds are strongly toxic due to phorbol esters in the kernel (Goel et al., 2007). These cannot be destroyed completely but can be greatly reduced by hightemperature treatment (Makkar et al., 1998), alkalization treatment (Rakshit et al., 2008), microbial fermentation (Makkar and Becker, 2010) and organic solvent extraction (Devappa et al., 2010). According to some reports, when fish, chicks, pigs, goat, mice and rats were force-fed raw or defatted jatropha meal, severe toxicity symptoms were observed on the animals before death (Adam and Magzoub, 1975; Broderick and Craig, 1980; Abdu-Aguye et al., 1986; Liberalino et al., 1988; Chivandi et al., 2000; Gadir et al., 2003). In the goat's autopsy, hemorrhage in rumen, kidney, spleen and heart, enteritis and liquid edema in lung lobe were observed (Adam and Magzoub, 1975). Pigs fed jatropha meal heated to $121^{\circ} \mathrm{C}$ did not show abnormalities in blood parameters or the viscera (Wang et 
al., 2011). However, ruminants fed jatropha meal treated by alkalization for 90 days did show abnormalities in blood indexes and liver function parameters (Katole et al., 2011). In ruminants, the fermentation characteristics of the rumen are important for evaluating feedstuff in diets. To our knowledge, there are no reported data on the influence in ruminants fed jatropha meal in terms of ruminal fermentation characteristics. Thus, it is important to observe the effects on ruminal fermentation and blood characteristics when ruminants are fed jatropha meal. Therefore, this experiment decides to process the jatropha residual through heat treatment and means to further verify the effectiveness of heat treatment on degradation of phorbal ester.

The rapeseed is the common raw material as supplemented protein in concentrated feed in general market. The protein content of rapeseed is similar to that of the Jatropha residue. Therefore, Jatropha residue has the potential to be the source of protein added to the concentrated feed. Therefore, this experiment uses rapeseed as the control group.

The objectives of this study were to investigate feed intake, blood biochemical indices, and ruminal fermentation in sheep fed concentrate mixed with jatropha meal after heat treatment as well as to explore reasonable utilization methods of jatropha meal for sheep.

\section{MATERIALS AND METHODS}

This experiment was conducted with approval from the Committee on Animal Experimentation and under the institutional guidelines for animal experiments of Yamagata University.

\section{Animals and feeding diets}

The experimental animals used included six wethers, Corriedale $\times$ Coopworth (The sheep had rumen fistula, and their average initial body weight was $43 \mathrm{~kg}$, and average age was 3 years old.). They were divided randomly into two groups. Animals were fed a basal diet and an experimental diet. The basal diet contained roughage (reed canary grass hay) and commercial concentrate.The experimental diets included rapeseed meal and jatropha meal. Jatropha meal was heated at $185^{\circ} \mathrm{C}$ for $30 \mathrm{~min}$. In Japan according to the sheep feeding standard (Central Association of Livestock Industry, 1996), all animals were given a maintenance level per day based on body weight ( $2 \%$ of body weight in dry matter) and free access to clean drinking water. They were fed twice daily at 09.00 and 17.00 hours. Rapeseed meal and jatropha meal was replaced to the feed as a concentrate with proportion of $5 \%$ in experiment I and $10 \%$ in experiment II. Roughage and concentrate were administered in a 1:1 ratio. The experimental design used two treatments (rapeseed diet; RMD and jatropha diet; JMD) and was conducted with a cross-over design. The experimental periods consisted of an acclimatization period of 10 days and an experimental period of 7 days. Feed intake was recorded every $10 \mathrm{~min}$ until $120 \mathrm{~min}$ after feeding on the $4^{\text {th }}$ and $5^{\text {th }}$ days of the experimental period (every $10 \mathrm{~min}$ the remained diets in the feeding trough was recorded). In order to avoid interaction effect between the two experiments, the sheep were fed with 10- day basal diet contained roughage (reed canary grass hay) and commercial concentrate, then the experiment I was conducted feeding with the animals with the experimental diet (10-day adaptation period and 5-day experimental period); after experiment I, the animals were fed with basal diet contained roughage (reed canary grass hay) and commercial concentrate continually, then the experiment II was conducted.

\section{Sampling methods}

Blood was collected from the jugular vein of the sheep at before the morning feeding on the last day of each experimental period. The blood sample was separated by centrifugation $(11,000 \mathrm{rpm})$ to prepare plasma, which was stored at $-20^{\circ} \mathrm{C}$ until the analyses of blood biochemical parameters. $20 \mathrm{ml}$ fresh rumen fluid was collected from the rumen stomach fistula in the sheep at three different times: at $0 \mathrm{~h}$ (before the morning feeding), $2 \mathrm{~h}$ and $4 \mathrm{~h}$ after the morning feeding on the last day. The rumen fluid sample was then double gauze-filtered and stored at $-20^{\circ} \mathrm{C}$ until analyzed.

\section{Chemical and analyses}

Samples of the basal diet and the experimental diets were ground using a mill with a $0.5-\mathrm{mm}$ screen. The moisture, ash, nitrogen, ether extract, and crude fiber contents of the feeds were determined according to conventional methods (Horii et al., 1971). The neutral detergent fiber (NDF) and acid detergent fiber (ADF) contents of the feeds were analyzed according to the method of Van Soest et al. (1991). Untreated and heattreated jatropha meal samples were sent to Shimadzu Techno-Research, Inc. for analysis of the phorbol ester content. Take $1 \mathrm{~g}$ of the samples after crushing, add $10 \mathrm{~mL}$ alcohol (Kanto Chemical Co., Inc, Tokyo, Japan) and leave for $12 \mathrm{~h}$. After it was treated by ultrasonic waves and 30 min vibration, use centrifugal separation. Supernatant was filter by $0.45 \mathrm{~nm}$ membrane filter and used for analyze. LC-10A system API-4000 (Shimadzu Corporation, kyoto, Japan) was used in analysis meter. Column is Intertsil ODS-3 (GL Sciences Inc, Tokyo, Japan) temperature level was set at $40^{\circ} \mathrm{C}$, velocity was set at $0.2 \mathrm{~mL} / \mathrm{min}$, does was 
$5 \mathrm{uL}$. And the accuracy was measured to be $10 \mathrm{ppm}$ under LC/MS (Wilhelm and Martin., 2000; Gaudani et al., 2009)

The isolated plasma samples were analyzed for glucose, urea nitrogen, and non-esterified fatty acids (NEFA) concentrations using test kits from Diasys Diagnostic Systems (Wako Pure Chemical Industries, Tokyo, Japan). Glutamic-oxaloacetic transaminase, glutamic-pyruvic transaminase, lysozyme dehydrogenase, alkaline phosphatase, $\gamma$-glutamyl transpeptidase and cholinesterase, which are parameters relevant to liver function, were analyzed by a clinical examination analysis company (SRL Inc., Tokyo, Japan). In rumen fluid, the $\mathrm{pH}$ was determined using a $\mathrm{pH}$ meter (D-21; Horiba, Kyoto, Japan). Ruminal $\mathrm{NH}_{3}-\mathrm{N}$ concentration was determined by the micro diffusion method (Conway, 1962). The volatile fatty acid (VFA) concentration was determined by the method of Hamada (1971) using gas chromatography (G-5000A; Hitachi, Tokyo, Japan).

\section{Statistical analyses}

All data were shown as means \pm standard error of the means. Analyses were performed using the general linear model procedure (SAS Institute Inc., Cary, NC, USA). The feeding periods were analyzed according to obtained data, and no difference was found among feeding periods. Thus $t$-test $(p<0.05)$ was used to analyze the data of blood parameters and rumen fermentation of two treatments.

\section{RESULTS}

Chemical content of roughage, concentrated feed, jatropha meal and rapeseed meal

The phorbol ester (dry matter) content was $30.7 \mu \mathrm{g}$ $\mathrm{g}^{-1}$ for the original jatropha meal, and this decreased to $5.1 \mu \mathrm{g} \mathrm{g}^{-1}$ after the $185^{\circ} \mathrm{C}$ heat treatment (Fig. 1). CP, EE and NDFom contents of roughage and concentrated feed were $13.7 \%, 1.5 \%, 67.5 \%$ and $15.8 \%, 4.9 \%, 39.2 \%$ respectively. The $\mathrm{CP}$ content of heat-treated jatropha meal was $27.8 \%$, lower than that of rapeseed meal $(42.7 \%)$. The EE content of heat-treated jatropha meal $(6.0 \%)$ was greater than that of rapeseed meal $(2.6 \%)$. The NDFom and ADFom content $(49.2 \%$ and $41.5 \%$ respectively) was greater than that of rapeseed meal $(26 \%$ and $18.4 \%$ respectively) (Table I, $\mathrm{P}<0.05$ ).

\section{Experiment I}

The feed intake speed of the JMD was slower than that of the RMD. And JMD was eaten up fully after $70 \mathrm{~min}$ (Fig. 2). Feed intake of RMD (80.4\%) was greater than that of JMD $(64.0 \%)$ at $20 \mathrm{~min}(\mathrm{p}<0.05)$. After 40 and $50 \mathrm{~min}$, feed intake of JMD ( $89.1 \%$ and $93.3 \%$, respectively) was lower than that of RMD $(96.6 \%$ and $99.0 \%$, respectively,
$\mathrm{P}<0.05)$.

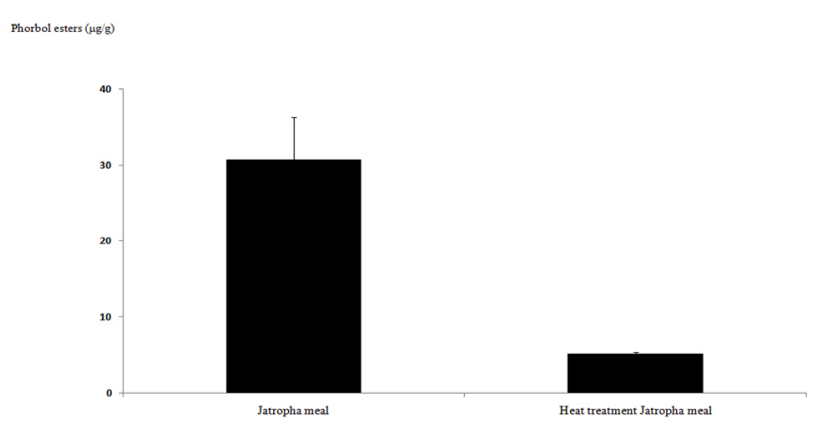

Fig. 1. Content of phorbol esters in jatropha meal.

Table I. Chemical composition of roughage, concentrate, rapeseed meal and heat-treated jatropha meal.

\begin{tabular}{|c|c|c|c|c|}
\hline & $\begin{array}{l}\text { Rough- } \\
\text { age }\end{array}$ & $\begin{array}{l}\text { Concen- } \\
\text { trate }\end{array}$ & $\begin{array}{l}\text { Rapeseed } \\
\text { meal }\end{array}$ & $\begin{array}{l}\text { Heat-treated } \\
\text { jatropha meal }\end{array}$ \\
\hline Moisture (\%) & $6.5^{y}$ & $9.2^{\mathrm{x}}$ & 11.3 & 8.1 \\
\hline Crude protein $(\% \mathrm{DM})$ & $13.7^{\mathrm{y}}$ & $15.8^{\mathrm{x}}$ & $42.7^{\mathrm{a}}$ & $27.8^{\mathrm{b}}$ \\
\hline Ether extract $(\% \mathrm{DM})$ & $1.5^{\mathrm{y}}$ & $4.9^{\mathrm{x}}$ & $2.6^{\mathrm{b}}$ & $6.0^{\mathrm{a}}$ \\
\hline NDFom (\%DM) & $67.8^{\mathrm{x}}$ & $39.2^{\mathrm{y}}$ & $26.0^{\mathrm{b}}$ & $49.2^{\mathrm{a}}$ \\
\hline ADFom (\%DM) & $49.5^{\mathrm{x}}$ & $10.0^{\mathrm{y}}$ & $18.4^{\mathrm{b}}$ & $41.5^{\mathrm{a}}$ \\
\hline Crude ash (\%DM) & $11.9^{\mathrm{x}}$ & $4.5^{\mathrm{y}}$ & $7.1^{\mathrm{a}}$ & $6.4^{\mathrm{b}}$ \\
\hline
\end{tabular}

DM, Dry matter; NDFom, Neutral detergent fiber exclusive of residual ash; ADFom, Acid detergent fiber exclusive of residual ash. ${ }^{a . b}$ Means with different between rapeseed meal and Heat-treated jatropha meal significantly differ $(p<0.05)$. ${ }^{\mathrm{x}, \mathrm{y}}$ Means with different between roughage and concentrate significantly differ $(p<0.05)$.

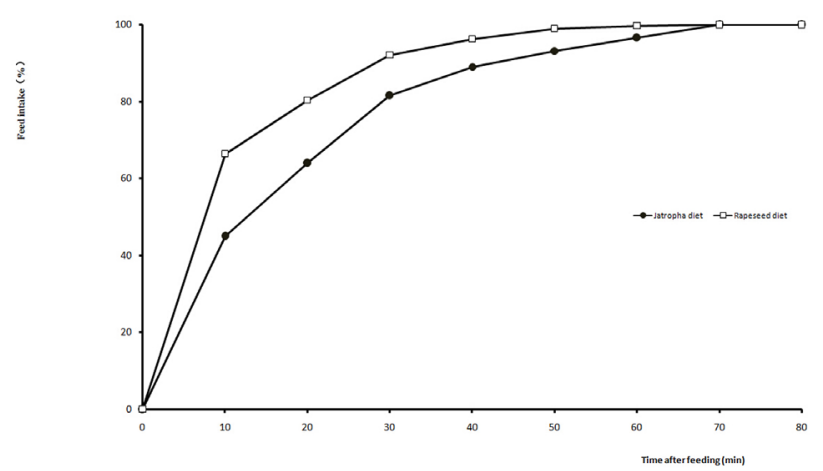

Fig. 2. Effects of the feeding diet on intake in sheep (Experiment I).

The hematocrit (32.0\%), glucose $(48.4 \mathrm{mg} / \mathrm{dL}), \mathrm{BUN}$ $(16.7 \mathrm{mg} / \mathrm{dL})$, NEFA $(0.3 \mathrm{mEq} / \mathrm{L})$, GOT $(62.9 \mathrm{IU} / \mathrm{L})$, GPT (13.7 IU/L), LD (382 IU/L), AP (291.8 IU/L), GTP (67.7 IU/L), and cholinesterase (5.0 IU/L) contents of 
wethers fed RMD were not shown obvious differences when compared with blood parameter of wethers fed JMD (hematocrit; 33\%, glucose; $52.5 \mathrm{mg} / \mathrm{dL}, \mathrm{BUN} ; 15.4 \mathrm{mg} /$ dL, NEFA; 0.4 mEq/L, GOT; 68.4 IU/L, GPT; 14.8 IU/L, LD; 388.5 IU/L, AP; $280.8 \mathrm{IU} / \mathrm{L}$, GTP; $68.0 \mathrm{IU} / \mathrm{L}$, and cholinesterase; $5.0 \mathrm{IU} / \mathrm{L}$, contents, Table II)

Table III shows the fermentation characteristics of the rumen fluid at 0,2 and $4 \mathrm{~h}$ in experiment $\mathrm{I}$. After $0 \mathrm{~h}$, the $\mathrm{pH}$ and total VFA concentration of RMD and JMD were $6.7,8.1 \mathrm{mmol} / \mathrm{dL}$ and $6.8,6.6 \mathrm{mmol} / \mathrm{dL}$ respectively. After $2 \mathrm{~h}$, the $\mathrm{pH}$, total VFA concentration, acetic acid, propionic acid, butyric acid and volatile nitrogen concentration of RMD and JMD were 5.8, $11.8 \mathrm{mmol} / \mathrm{dL}, 43.3 \% \mathrm{~mol}$, $35.1 \% \mathrm{~mol}, 17.7 \% \mathrm{~mol}, 14.5 \mathrm{~mol} / \mathrm{dL}$ and $5.8,11.7 \mathrm{mmol} /$ $\mathrm{dL}, 40.4 \% \mathrm{~mol}, 35.9 \% \mathrm{~mol}, 19.1 \% \mathrm{~mol}, 16.5 \mathrm{~mol} / \mathrm{dL}$ respectively. After $4 \mathrm{~h}$, the $\mathrm{pH}$, total VFA concentration, acetic acid, propionic acid, butyric acid and volatile nitrogen concentration of RMD were $5.9,10.7 \mathrm{~mm} \mathrm{~mol} / \mathrm{dL}$, $39.1 \% \mathrm{~mol}, 36.1 \% \mathrm{~mol}, 21.4 \% \mathrm{~mol}, 11 \mathrm{~mol} / \mathrm{dL}$. Those of JMD were 5.5, $11.8 \mathrm{~mol} / \mathrm{dL}, 39.2 \% \mathrm{~mol}, 37.9 \% \mathrm{~mol}, 17.1$ $\% \mathrm{~mol}, 5.3 \mathrm{~mol} / \mathrm{dL}$ respectively. The results showed that there were no obvious differences between $\mathrm{pH}$, total VFA concentration, acetic acid, propionic acid, butyric acid and volatile nitrogen concentration in rumen fluid at 0,2 or 4 $\mathrm{h}$ after feeding.

Table II. Effects of the feeding diets with RMD and JMD on blood parameters in wethers (Experiment I).

\begin{tabular}{llll}
\hline & RMD & JMD & SEM \\
\hline Hematocrit (\%) & 32.0 & 33.0 & 0.5 \\
Glucose (mg/dL) & 48.4 & 52.5 & 2.5 \\
BUN (mg/dL) & 16.7 & 15.4 & 0.7 \\
NEFA (mEq/L) & 0.3 & 0.4 & 0.0 \\
GOT (IU/L) & 65.5 & 68.2 & 6.4 \\
GPT (IU/L) & 13.0 & 13.0 & 0.9 \\
LD (IU/L) & 378.7 & 390.7 & 42.1 \\
AP (IU/L) & 307.5 & 307.3 & 31.2 \\
$\gamma$-GTP (IU/L) & 66.7 & 67.5 & 2.4 \\
Cholinesterase(IU/L) & 5.0 & 5.0 & 0.0 \\
\hline
\end{tabular}

RMD, Rapeseed meal diet; JMD, Jatropha meal diet; BUN, Blood urea nitrogen; NEFA, Non-esterified fatty acid; GOT, Glutamic-oxaloacetic transaminase; GPT, Glutamic-pyruvic transaminase; LD, Lysozyme dehydrogenase; AP, Alkaline phosphatase; $\gamma$-GTP, $\gamma$-glutamyl transpeptidase; SEM, Standard error of means.

\section{Experiment II}

In experiment II, Figure 3 shows the feed intake speed of the two diets after $10 \%$ of experimental diet was replaced. After 20 and $40 \mathrm{~min}$, feed intake of RMD (78.5\% and $96.3 \%)$ was greater than that of JMD $(42.3 \%$ and
$58.1 \%$ ) respectively, and feed intake of RMD was $100 \%$ at $60 \mathrm{~min}$. After $90 \mathrm{~min}$ and $120 \mathrm{~min}$, feed intake of JMD was $81.1 \%$ and $84.5 \%$ respectively $(\mathrm{P}<0.05)$.

The hematocrit $(31.0 \%)$, glucose $(54.5 \mathrm{mg} / \mathrm{dL}), \mathrm{BUN}$ (19.3 mg/dL), NEFA (0.3 mEq/L), GOT (65.5 IU/L), GPT (13.0 IU/L), LD (378.7 IU/L), AP (307.5 IU/L), GTP (67.7 $\mathrm{IU} / \mathrm{L})$ and cholinesterase (5.0 IU/L) contents of wethers fed RMD were not shown obvious differences when compared with blood parameter of wethers fed JMD (hematocrit; 33\%, glucose; $55.6 \mathrm{mg} / \mathrm{dL}, \mathrm{BUN} ; 17.6 \mathrm{mg} / \mathrm{dL}$, NEFA; $0.45 \mathrm{mEq} / \mathrm{L}, \mathrm{GOT} ; 68.2 \mathrm{IU} / \mathrm{L}, \mathrm{GPT} ; 13.0 \mathrm{IU} / \mathrm{L}, \mathrm{LD} ; 390.7$ IU/L, AP; 307.3 IU/L, GTP; 67.5 IU/L and cholinesterase; $5.0 \mathrm{IU} / \mathrm{L}$, contents, Table IV).

Table III. Effects of the feeding diets with RMD and JMD on ruminal fermentation characteristics in wethers (Experiment I).

\begin{tabular}{lllll}
\hline & $\begin{array}{l}\text { Hours after } \\
\text { feeding }\end{array}$ & RMD & JMD & SEM \\
\hline $\mathrm{pH}$ & 0 & 6.7 & 6.8 & 0.2 \\
& 2 & 5.8 & 5.8 & 0.2 \\
& 4 & 5.9 & 5.5 & 0.2 \\
Total VFA (mmol/dL) & 0 & 8.1 & 6.6 & 0.7 \\
& 2 & 11.8 & 11.7 & 0.7 \\
Acetic acid (\% mol) & 4 & 10.7 & 11.8 & 0.7 \\
& 0 & 38.7 & 40.7 & 3.1 \\
Propionic acid (\% mol) & 0 & 43.3 & 40.4 & 4.0 \\
& 2 & 39.1 & 39.2 & 4.5 \\
& 2 & 32.8 & 34.2 & 1.0 \\
Butyric acid (\% mol) & 0 & 35.1 & 35.9 & 1.1 \\
& 4 & 36.1 & 37.9 & 1.4 \\
& 2 & 15.0 & 13.6 & 1.0 \\
& 4 & 17.7 & 19.1 & 2.9 \\
A/P & 4 & 21.4 & 17.1 & 4.6 \\
& 0 & 1.1 & 1.2 & 0.1 \\
& 2 & 1.2 & 1.1 & 0.1 \\
& 4 & 1.1 & 1.1 & 0.1 \\
& 4 & 17.2 & 16.2 & 2.6 \\
& 0 & 14.5 & 16.5 & 5.8 \\
& 2 & 11.0 & 5.3 & 3.9 \\
\hline
\end{tabular}

RMD, Rapeseed meal diet; JMD, Jatropha meal diet; VFA, Volatile fatty acid; A/P, Ratio of acetic acid to propionic acid; SEM, Standard error of the means.

Table V shows the ruminal fermentation characteristics before $(0 \mathrm{~h})$ and after fed $(2$ and $4 \mathrm{~h})$. The total VFA concentration in rumen fluid of the JMD tended $(8.2 \mathrm{mmol} /$ 
dL) lower than that of the RMD (10.7 mmol/dL) after $2 \mathrm{~h}$ feeding, however, there were no obvious difference between JMD and RMD before and after $4 \mathrm{~h}$ feeding (Table V). There were no obvious differences in acetic acid, propionic acid and volatile nitrogen concentration between the RMD and the JMD after feeding the wethers 2 or $4 \mathrm{~h}$, however, butyric acid concentration in the RMD $(24.1 \% \mathrm{~mol})$ after feeding the wethers $2 \mathrm{~h}$ was higher than that in JMD $(20.3 \% \mathrm{~mol})(\mathrm{P}<0.05)$.

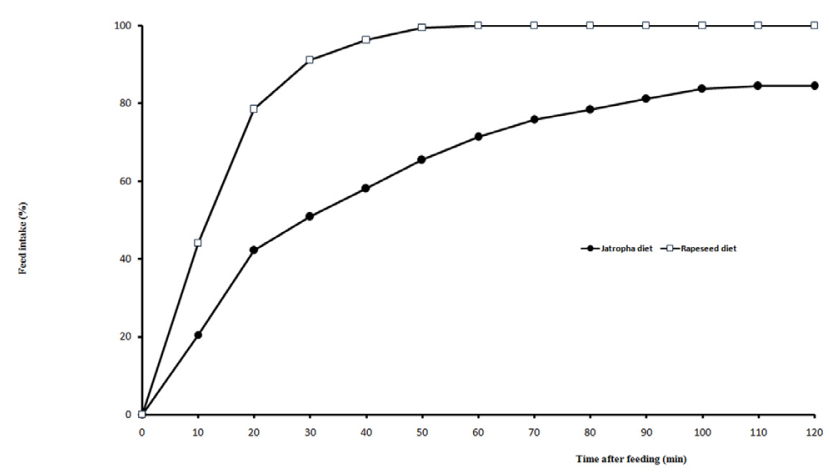

Fig. 3. Effects of the feeding diet on intake in sheep (Experiment II).

Table IV. Effects of the feeding diets with RMD and JMD on blood parameters in wethers (Experiment II).

\begin{tabular}{llll}
\hline & RMD & JMD & SEM \\
\hline Hematocrit (\%) & 31.0 & 33.0 & 0.8 \\
Glucose (mg/dL) & 54.5 & 55.6 & 1.3 \\
BUN (mg/dL) & $19.3^{\mathrm{a}}$ & $17.6^{\mathrm{b}}$ & 0.4 \\
NEFA (mEq/L) & 0.3 & 0.5 & 0.0 \\
GOT (IU/L) & 65.2 & 66.8 & 5.9 \\
GPT (IU/L) & 13.7 & 14.8 & 1.1 \\
LD (IU/L) & 382.0 & 388.5 & 32.0 \\
AP (IU/L) & 291.8 & 280.8 & 38.5 \\
$\gamma$-GTP (IU/L) & 67.7 & 68.0 & 3.3 \\
Cholinesterase (IU/L) & 5.0 & 5.0 & 0.0 \\
\hline
\end{tabular}

RMD, Rapeseed meal diet; JMD, Jatropha meal diet; BUN, Blood urea nitrogen; NEFA, Non-esterified fatty acid; GOT, Glutamicoxaloacetic transaminase; GPT, Glutamic-pyruvic transaminase; LD, Lysozyme dehydrogenase; AP, Alkaline phosphatase; $\gamma$-GTP, $\gamma$-Glutamyl transpeptidase; SEM, Standard error of means.

\section{DISCUSSION}

There have been many studies on the phorbol ester concentration in Jatropha curcas and its potential use in livestock feed (Chivandi et al., 2004). Rakshit et al. (2008) showed that extracted jatropha residue remained
Table V. Effects of the feeding diets with RMD and JMD on ruminal fermentation characteristics in wethers (Experiment II).

\begin{tabular}{|c|c|c|c|c|}
\hline & $\begin{array}{l}\text { Hours after } \\
\text { feeding }\end{array}$ & RMD & JMD & SEM \\
\hline \multirow[t]{3}{*}{$\mathrm{pH}$} & 0 & 6.8 & 6.7 & 0.1 \\
\hline & 2 & 6.3 & 6.5 & 0.2 \\
\hline & 4 & 6.2 & 6.2 & 0.2 \\
\hline \multirow[t]{3}{*}{ Total VFA (mmol/dL) } & 0 & 6.6 & 6.7 & 0.3 \\
\hline & 2 & $10.7^{\mathrm{a}}$ & $8.2^{\mathrm{b}}$ & 0.2 \\
\hline & 4 & 9.6 & 8.9 & 0.5 \\
\hline \multirow[t]{3}{*}{ Acetic acid (\% mol) } & 0 & 40.3 & 41.1 & 1.0 \\
\hline & 2 & 36.1 & 38.4 & 1.2 \\
\hline & 4 & 37.3 & 37.2 & 1.1 \\
\hline \multirow[t]{3}{*}{ Propionic acid (\% mol) } & 0 & 33.1 & 31.5 & 0.6 \\
\hline & 2 & 31.3 & 32.2 & 0.8 \\
\hline & 4 & 32.2 & 31.3 & 1.0 \\
\hline \multirow[t]{3}{*}{ Butyric acid (\% mol) } & 0 & 14.4 & 14.4 & 0.5 \\
\hline & 2 & $24.1^{\mathrm{a}}$ & $20.3^{\mathrm{b}}$ & 1.1 \\
\hline & 4 & 21.9 & 24.1 & 1.1 \\
\hline \multirow[t]{3}{*}{$\mathrm{A} / \mathrm{P}$} & 0 & 1.2 & 1.3 & 0.0 \\
\hline & 2 & 1.2 & 1.2 & 0.0 \\
\hline & 4 & 1.2 & 1.2 & 0.1 \\
\hline \multirow[t]{3}{*}{$\mathrm{NH}_{3}-\mathrm{N}(\mathrm{mg} / \mathrm{dL})$} & 0 & 16.3 & 15.5 & 1.4 \\
\hline & 2 & 18.5 & 13.5 & 1.7 \\
\hline & 4 & 10.3 & 11.1 & 2.0 \\
\hline
\end{tabular}

RMD, Rapeseed meal diet; JMD, Jatropha meal diet; VFA, Volatile fatty acid; A/P, Ratio of acetic acid to propionic acid; SEM, Standard error of the means; ${ }^{\mathrm{a}, \mathrm{b}} \mathrm{Means}$ with different between roughage and concentrate significantly differ $(p<0.05)$.

toxic and caused adverse effects in animals. In their report, mice died after being fed the defatted Jatropha curcas residue after high pressure and alkalization treatment. A previous report (Oskoueian et al., 2011) showed that the content of phorbol esters was clearly reduced by rumen microbial fermentation treatment. Most of the phorbol esters of jatropha meal can be removed by heating (Makkar et al., 1997; Becker and Makkar, 1998; Chivandi et al., 2006; Rakshit et al., 2008; Katole et al., 2011; Wang et al., 2011). Furthermore, there are reports of no adverse effects in animals fed heat-treated jatropha meal (Wang et al., 2011). Thus, it seems that high temperatures treatment to jatropha meal can reduce the phorbol ester content. It has also been reported that the phorbol ester contents in different species of Jatropha curcas kernel vary from 0.87 to $3.32 \mathrm{mg} / \mathrm{g}$ (Makkar et al., 1997). The phorbol 
ester content of jatropha meal used in this experiment, $30.7 \mu \mathrm{g} \mathrm{g}^{-1}$, which was lower than that in other studies. The phorbol ester contents of jatropha meal are influenced by the technique used for oil extraction, the breed, and preserving conditions. It is necessary to further verify the inhibition effect of heat treatment on phorbol esters and to discuss the influence of heat-treated jatropha residual on ruminants. It was suggested the phorbol esters content of jatropha meal used in the experiment is reduced by heat treatment of $185^{\circ} \mathrm{C}$. In future study, we will continue to explore more effective and safer treatment to reduce the amount of phorbol esters.

Heated treatment was good for ruminant to utilize protein, inactivated the trypsin inhibitor, and increased the number of Undegradable protein entering into the alvine (Demjanec et al., 1995). However, excessive heated treatment would have opposite effect which would decrease the number of bypass protein entering into the abomasus and alvine (Makkar et al., 2008). Studies done by Aderibigbe et al. (1997) indicated that the time of heated treatment did not have remarkable influence on the decomposing rate, while the temperature influenced the decomposing rate of jatropha in rumen. Therefore, the proper heated treatment method will be the objective of our study in future.

In this study, it was shown that jatropha meal was rich in crude protein and fiber components. The amino acid mix in jatropha meal is similar to that in soybean meal (Vasconcelos et al., 1997; Makkar et al., 1998). Thus, jatropha meal has the potential to replace other crude protein sources in livestock feed (Aregheore et al., 2003; Wang et al., 2011). After $30 \mathrm{~min}$ heat treatment, jatropha meal can safely replace $10 \%$ of feeding diets in pigs (Wang et al., 2011). Katole et al. (2011) and Wang et al. (2011) used jatropha meal in place of crude protein in livestock diets; because of its rich protein content and the increasingly difficult choices of protein source worldwide (Chivandi et al., 2006). The fiber component, as ADF and NDF, in jatropha meal in this study was higher than that in rapeseed meal, because the Jatropha curcas kernel coat had not been peeled off. Tagawa et al. (2013) also reported that the ADF and NDF contents of jatropha meal were higher than those in rapeseed meal and soybean meal.

In experiment I, jatropha meal was processed by heat treatment and was replaced to feeding diets as a concentrate in proportion of $5 \%$. The ingestion speed of sheep fed the jatropha diet was slower than that of sheep fed the rapeseed diet, although both were ingested fully. Heat-treated jatropha meal did show a lower acceptability. In experiment II, after $10 \%$ of experimental diet was replaced, the jatropha diet was not totally ingested, and the palatability was bad. In addition, the roughage (reed canary grass hay) was ingested by animals completely, and the concentrate mixed with jatropha residue was remained. Animals may be sensitive even to low phorbol ester contents in heated jatropha meal. Feed selection in the ruminants may involve interactions between the senses of smell and taste (Provenza, 1995). The hardness of jatropha meal may also have been uncomfortable for the ruminants. The exposure of unfavorable meals in diet could also influence the ingestion of the animals (Nombekela et al., 1994). In particular, differences in the chemical and physical compositions may affect the taste and texture of the feed meal, and thus, the preferences of the animals (Nombekela et al., 1994). It is important to further investigate the palatability of jatropha meal after different treatments, including chemical and/or physical processing, and to further reduce its phorbol esters contents.

Except the BUN concentration in Experiment II, all blood indicators of liver function were nearly the same between the rapeseed diet and the jatropha diet and showed no abnormalities. Furthermore, the blood indicators in experiment I and II were all within normal ranges (Cynthia et al., 2010). In experiment II, due to the addition of jatropha meal, the crude protein in the daily diets of animal decreased, therefore, the BUN concentration in JMD was lower than that in RMD.S imilarly, ruminal $\mathrm{NH}_{3}-\mathrm{N}$ concentrations and blood urea nitrogen concentrations are related (De Peters and Ferguson, 1992). Our results were consistent with these previous reports. There were no abnormity and obvious difference on blood parameters in experiment I and II. But the BUN concentration in experiment II was higher than that in experiment I, which was because the added protein feed, led to the higher crude protein content in meal and higher nitrogen concentration in blood. Every index of liver function was nearly the same between two treatments in experiment I and II, which may because of the short test period so that the phorbel esters have not made obvious influence on the animals. Thus, medium and long term animals feeding experiment is needed in future.

Total VFA concentrations in ruminants depend on the kind of feed and the fermentation of feed in the rumen (Firkins et al., 1986; Robinson et al., 1986). In this experiment I, the ruminal fermentations were nearly the same between sheep fed the rapeseed diet versus the jatropha diet; no negative effect of jatropha meal was noted. Total VFA concentrations in sheep fed the jatropha diet did not decrease $4 \mathrm{~h}$ after feeding; this may have been because the intake rate influenced the ruminal fermentation. However, there was no statistically significant difference. In the future, a study with more animals would be useful to confirm these results. In experiment II, total VFA 
concentrations of the jatropha diet was significantly low at $2 \mathrm{~h}$ after feeding. It is because of the low feed intake of sheep fed the jatropha diet, consequently affecting rumen fermentation. In the future experiment, we will have a detailed analysis about jatropha meal have influence on rumen fermentation under the different treatment.

In the $5 \%$ adding experiment, the average phorbol esters intake was $0.2 \mathrm{mg}$ per day. In the jatropha residue, those low-content phorbol esters are likely to be metabolized by the animal itself, which will not make negative effect. In this experiment, poisoning phenomenon did not show in the experimental animals. However, we could not assume accordingly if these intaken phorbol esters would make potential damage to other organs.In future study; we will examine it by pathological means.

\section{CONCLUSION}

In conclusion, these experiments showed that feeding $5 \%$ heat-treated jatropha meal had no apparent negative effect on the sheep. In future work, we will assess different methods of processing jatropha meal and conduct a feeding trial using jatropha meal over the mid and long-term. We will also continue to observe the animals, testing all indices of blood biochemistry and rumen microorganisms.

\section{ACKNOWLEDGEMENT}

This work was supported by the Natural Science Foundation of Hainan Province, China (Number: 2019RC322).

\section{Statement of conflict of interest}

The authors declare there is no conflict of interest.

\section{REFERENCES}

Abdu-Aguye, I., Sannusi, A., Alafiya-Tayo, R.A. and Bhusnurmath, S.R., 1986. Acute toxicity studies with Jatropha curcas L. Hum. Exp. Toxicol., 5: 269274. https://doi.org/10.1177/096032718600500409

Adam, S.E. and Magzoub, M., 1975. A toxicity of Jatropha curcas for goats. Toxicology, 4: 347-354. https://doi.org/10.1016/0300-483X(75)90057-8

Aderibigbe, A.O., Johnson, C.O.L.E. and Makkar, H.P.S., 1997. Chemical composition and effect of heat on organic matter and nitrogen degradability and some anti-nutritional components of Jatropha meal. Anim. Feed Sci. Tech., 67: 223-243. https:// doi.org/10.1016/S0377-8401(96)01136-4

Akbar, E., Yaakob, Z., Kamarudin, S.K., Ismail, M. and Salimon, J., 2009. Characteristic and composition of Jatropha curcas oil seed from Malaysia and its potential as biodiesel feedstock. Eur. J. Sci. Res., 29: 396-403.

Aregheore, E.M., Becker, K. and Makkar, H.P.S., 2003. Detoxification of a toxic variety of Jatropha curcas using heat and chemical treatments and preliminary nutritional evaluation with rats. S. Pacif. J. Natur. Sci., 21: 50-56. https://doi.org/10.1071/SP03010

Becker, K. and Makkar, H.P.S., 1998. Effects of phorbol esters in carp (Cyprinus carpio L). Vet. Hum. Toxicol., 40: 82-86.

Broderick, G.A. and Craig, W.M., 1980. Effect of heat treatment on ruminal degradation and escape, and intestinal digestibility of cottonseed meal protein. J. Nutri., 110: 2381-2389. https://doi.org/10.1093/ jn/110.12.2381

Central Association of Livestock Industry. 1996. Japanese feeding standard for sheep. Agriculture, Forestry and Fisheries Research Council Secretariat, MAFF.

Chivandi, E., Makuza, S.M., Erlanger, K.H., Mtimuni, J.P., Read, J.S. and Tivapasi, M., 2000. Effects of dietary Jatropha curcas on the haematology of weaned pigs. Zim. Vet. J., 31: 83-91. https://doi. org/10.4314/zvj.v31i3.5360

Chivandi, E., Mtimuni, J.P., Read, J.S. and Makuza, S.M., 2004. Effect of processing method on the phorbol ester concentration, total phenolics, trypsin inhibitor activity and the proximate composition of the Zimbabwean. Jatropha curcas provenance: a potential livestock feed. Pak. J. biol. Sci., 7: 10011005. https://doi.org/10.3923/pjbs.2004.1001.1005

Chivandi, E., Erlwanger, K.H., Makuza, S.M., Read, J.S. and Mtimuni, J.P., 2006. Effects of dietary Jatropha curcas meal on percent packed cell volume, serum glucose, cholesterol and triglyceride concentration and alpha-amylase activity of weaned fattening pigs. Res. J. Anim. Vet. Sci., 1: 18-24.

Conway, E.J., 1962. Microdiffusion analysis and volumetric error. 5th edn. Crosby Lockwood, London.

Cynthia, M. and Kahn, B.A.M.A., 2010. The merck veterinary manual. 10th Edition, Merck Publishing, USA.

Demjanec, B., Merchen, N.R. and Cremin, J.D., 1995. Effect of roasting on site and extent of digestion of soybean meal by sheep: I. Digestion of nitrogen and amino acids. J. Anim. Sci., 73: 824-834. https:// doi.org/10.2527/1995.733824x

DePeters, E.J. and Ferguson, J.D., 1992. Non protein nitrogen and protein distribution in the milk of cows. J. Dairy Sci., 75: 3192-3209. https://doi. 
org/10.3168/jds.S0022-0302(92)78085-0

Devappa, R.K., Makkar, H.P.S. and Becker, K., 2010. Optimization of conditions for the extraction of phorbol esters from Jatropha oil. Biomass Bioener., 34: 1125-1133. https://doi.org/10.1016/j. biombioe.2010.03.001

Firkins, J.L., Berger, L.L., Merchen, N.R. and Fahez, Jr. G.C., 1986. Effects of forage particle size, level of feed intake and supplemental protein degradability on microbial protein synthesis and site of nutrient digestion in steers. J. Anim. Sci., 62: 1081-1094. https://doi.org/10.2527/jas1986.6241081x

Gadir, A., Onsa, T.O., Ali, W.E.M., El-Badwi, S.M.A. and Adam, S.E.I., 2003. Comparative toxicity of Croton macrostachys, Jatropha curcas, Piper abyssinica seeds in Nubian goats. Small Rumin. Res., 48: 6167. https://doi.org/10.1016/S0921-4488(02)00181-5

Goel, G., Makkar, H.P.S., Francis, G. and Becker, K., 2007. Phorbol esters: structure, biological activity, and toxicity in animals. Int. J. Toxicol., 26: 279-288. https://doi.org/10.1080/10915810701464641

Gubitz, G.M., Mittelbach, M. and Trabi, M., 1999. Exploitation of the tropical oil seed plant Jatropha curcas L. Bioresour. Technol., 67: 73-82. https://doi. org/10.1016/S0960-8524(99)00069-3

Hamada, T., 1971. Physicochemical analytical method for nutritional experiments. In: Animal nutrition testing method (ed. H. Morimoto), Yokendo, Tokyo, pp. 428-431. (In Japanese)

Heller, J., 1996. Physic nutrition Jatropha curcas L. Promoting the conservation and use of underutilized and neglected crops. 1. Institute of Plant Genetics and Crop Plant Research, Gatersleben/International Plant Genetic Resources Institute, Rome.

Gaudani, H., Gupta, M., Gupta, N., Trivedi, S., Patil, P., Gupta, G., Krishna, V., Reddy, K., Sethiya, M.P., Rathod, B.D. and M.R., 2009. Isolation and Characterization of phorbol esters (toxin) from the Jatropha curcas L. Int. J. Microbiol. Res., 1: 1-7.

Horii, S., Kurata, Y., Hayashi, Y. and Tanabe, S., 1971. Physicochemical analytical method for nutritional experiments. In: Animal nutrition testing method, 1st edn (ed. H. Morimoto), Yokendo, Tokyo, pp. 280-298. (In Japanese)

Katole, S., Saha, S.K., Sastry, V.R.B., Lade, M.H. and Prakash, B., 2011. Intake, blood metabolites and hormonal profile in sheep fed processed Jatropha (Jatropha curcas) meal. Anim. Feed Sci. Tech., 170: 21-26. https://doi.org/10.1016/j. anifeedsci.2011.07.017

Liberalino, A.A.A., Bambirra, E.A., Moraes-Santos, T. and Viera, C.E., 1988. Jatropha curcas L. seeds.
Chemical analysis and toxicity. Braz. Arch. Biol. Technol., 31: 539-550.

Makkar, H.P.S., Becker, K., Sporer, F. and Wink, M., 1997. Studies on nutritive potential and toxic constituents of different provenances of Jatropha curcas. J. Agric. Fd. Chem., 45: 3152-3157. https:// doi.org/10.1021/jf970036j

Makkar, H.P.S., Becker, K. and Schmook, B., 1998. Edible provenances of Jatropha curcas from Quintana Roo state of Mexico and effect of roasting on antinutrient and toxic factors in seeds. Pl. Fd. Hum. Nutri., 52: 31-36.

Makkar, H.P.S. and Becker, K., 1999. Nutritional studies on rats and fish (carp Cyprinus carpio) fed diets containing unheated and heated Jatropha curcas meal of a nontoxic provenance. Pl. Fd. Hum. Nutri., 53:183-192.

Makkar, H.P.S. and Becker, K., 2009. Jatropha curcas, a promising crop for the generation of biodiesel and value-added coproducts. Eur, J, Lipid Sci, Tech., 111: 773-787. https://doi.org/10.1002/ejlt.200800244

Makkar, H.P.S. and Becker, K., 2010. Are Jatropha curcas phorbol esters degraded by rumen microbes? J. Sci. Fd. Agric., 90: 1562-1565. https://doi.org/10.1002/ jsfa.3955

Makkar, H.P.S., Francis, G. and Becker, K., 2008. Protein concentrate from Jatropha curcas screw-pressed seed cake and toxic and antinutritional factors in protein concentrate. J. Sci. Fd. Agric., 89: 15421548. https://doi.org/10.1002/jsfa.3248

Nombekela, S.W., Murphy, M.R., Gonyou, H.W. and Marden, J.I., 1994. Dietary preferences in early lactation cows as affected by primary tastes and some common feed flavors. J. Dairy Sci., 77: 2393-2399. https://doi.org/10.3168/jds.S0022-0302(94)77182-4

Oskoueian, E., Abdullah, N., Saad, W.Z., Omar, A.R., Pateh, M.B. and Ho, Y.W., 2011. Anti-nutritional metabolites and effect of treated Jatropha curcas kernel meal on rumen fermentation in vitro. J. Anim. Vet. Adv., 10: 217-220. https://doi.org/10.3923/ javaa.2011.214.220

Provenza, F.A., 1995. Postingestive feedback as an elementary determinant of food preference and intake in ruminants. J. Range Manage., 48: 2-17. https://doi.org/10.2307/4002498

Rakshit, K.D., Darukeshwara, J., K. Rathina Raj, K., Narasimhamurthy, K., Saibaba, P. and Bhagya, S., 2008. Toxicity studies of detoxified Jatropha meal (Jatropha curcas) in rats. Fd. Chem. Toxicol., 46: 3621-3625. https://doi.org/10.1016/j. fct.2008.09.010

Robinson, P.H., Taminga, S. and Van Vuuren, A.M., 
1986. Influence of declining level of feed intake and varying the proportion of starch in the concentrate on rumen fermentation in dairy cows. Livest. Prod. Sci., 15: 173-189. https://doi.org/10.1016/03016226(86)90026-6

SAS, 1995. SAS/STAT user's guide, Version 9.2 Edition. SAS Institute, Cary, NC, USA.

Tagawa, S., Lv, R. and Horiguchi, K., Yoshida, N., Takahashi, T., Ichihara, S. and Hishinuma, S., 2013. Chemical composition, in vitro digestibility, gas production and methane production of Jatropha (Jatropha curcas L.) meal. Jpn. J. Grassl. Sci., 59: 120-123. (In Japanese)

Van Soest, P.J., Robertson, J.B. and Lewis, B.A., 1991. Methods for dietary fiber, neutral detergent fiber, and non-starch polysaccharides in relation to animal nutrition. J. Dairy Sci., 74: 3583-3597. https://doi. org/10.3168/jds.S0022-0302(91)78551-2
Vasconcelos, I.M., Siebra, E.A. and Maia, A.A.B., Moreira, R.A., Neto, A.F., Campelo, G.J.A. and Oliveira, J.T.A., 1997. Composition, toxic and antinutritional factors of newly developed agglutinin from soybean in the small intestine of the rat. $J$. Agric. Fd. Chem., 43: 165-170.

Wang, H.F., Chen, Y., Zhao, Y.N., Liu, H.Y., Liu, J.X., Makkar, H.P.S. and Becker, K., 2011. Effects of replacing soybean meal by detoxified Jatropha curcas kernel meal in the diet of growing pigs on their growth, serum biochemical parameters and visceral organs. Anim. Feed Sci. Tech., 170: 141146.

Wilhelm Haas and Martin Mittelbach, 2000. Detoxification experiments with the seed oil from Jatropha curcas L. Ind. Crop Prod., 12: 111-118. https://doi.org/10.1016/S0926-6690(00)00043-1 